\title{
Current Therapeutic Approach to Hypertrophic Scars
}

\author{
Zrinka Bukvić Mokos ${ }^{1 *}$, Anamaria Jović1, Lovorka Grgurević2, Ivo Dumić-Čule², \\ Krešimir Kostović ${ }^{1}$, Romana Čeović ${ }^{1}$ and Branka Marinović ${ }^{1}$
}

'Department of Dermatology and Venereology, University Hospital Centre Zagreb, School of Medicine, University of Zagreb, Zagreb, Croatia, ${ }^{2}$ Laboratory for Mineralized Tissues, School of Medicine, University of Zagreb, Zagreb, Croatia

OPEN ACCESS

Edited by:

Gregor Jemec,

University of Copenhagen,

Denmark

Reviewed by:

Cristina Has,

Albert Ludwig University

of Freiburg, Germany

Elisabetta Palazzo,

Universita' di Modena, Italy

*Correspondence:

Zrinka Bukvić Mokos zrinka.bukvic@zg.t-com.hr

Specialty section: This article was submitted

to Dermatology,

a section of the journal

Frontiers in Medicine

Received: 17 March 2017 Accepted: 06 June 2017

Published: 20 June 2017

Citation:

Mokos ZB, Jović A, GrgurevićL, Dumić-Čule I, Kostović K, Čeović R and Marinović $B$ (2017) Current

Therapeutic Approach to

Hypertrophic Scars.

Front. Med. 4:83.

doi: 10.3389/fmed.2017.00083
Abnormal scarring and its accompanying esthetic, functional, and psychological sequelae still pose significant challe nges. To date, there is no satisfactory prevention or treatment option for hypertrophic scars (HSs), which is mostly due to not completely comprehending the mechanisms underlying their formation. That is why the apprehension of regular and controlled physiological processes of scar formation is of utmost importance when facing hypertrophic scarring, its pathophysiology, prevention, and therapeutic approach. When treating HSs and choosing the best treatment and prevention modality, physicians can choose from a plethora of therapeutic options and many commercially available products, among which currently there is no efficient option that can successfully overcome impaired skin healing. This article reviews current therapeutic approach and emerging therapeutic strategies for the management of HSs, which should be individualized, based on an evaluation of the scar itself, patients' expectations, and practical, evidence-based guidelines. Clinicians are encouraged to combine various prevention and treatment modalities where combination therapy that includes steroid injections, 5-fluorouracil, and pulsed-dye laser seems to be the most effective. On the other hand, the current therapeutic options are usually empirical and their results are unreliable and unpredictable. Therefore, there is an unmet need for an effective, targeted therapy and prevention, which would be based on an action or a modulation of a particular factor with clarified mechanism of action that has a beneficial effect on wound healing. As the extracellular matrix has a crucial role in cellular and extracellular events that lead to pathological scarring, targeting its components mostly by regulating bone morphogenetic proteins may throw up new therapeutic approach for reduction or prevention of HSs with functionally and cosmetically acceptable outcome.

Keywords: wound healing, skin scarring, hypertrophic scar, scar management, topical therapy, prevention, treatment

\section{INTRODUCTION}

Skin is the largest organ in the human body that is in constant contact with the environment with its primary role to adapt to stresses and tension and to protect other systems within the body. When injured, it must rapidly repair itself to maintain the cutaneous integrity and its external defense function. As a response to injury, at the site of tissue disruption, the highly organized process of wound healing instantly begins and ultimately results in the formation of a scar that never obtains the flexibility or the strength of the original tissue (1). The fact that in the developed countries about 
100 million people per year form a dermal scar as a consequence of elective operations or injuries puts this problem among the most common in modern medicine and represents a huge cost to each health system $(2,3)$. We can expect around $30 \%$ of these to undergo abnormal growth due to aberrations in physiologic healing that result in hypertrophic scar (HS) or keloid formation, which are frequently accompanied by a number of esthetic, functional, and social impairments and may lead to decreased quality of life (4). Normotrophic, atrophic, hypertrophic, and keloid scars are all various types of scars with its different clinical appearance, etiology, and pathogenesis, demanding different therapeutic approach. The apprehension of regular and controlled physiological processes of scar formation is of the utmost importance when facing hypertrophic scarring, its pathophysiology, prevention, and therapeutic approach.

\section{METHODOLOGY}

In preparing this work, we used PubMed, Google Scholar, and Web of Science to perform literature searches on HS-related research. Key terms used in the search were "scarring," "wound healing," "hypertrophic scar," "scar management," "scar prevention," and "scar treatment." Review articles were used as an initial source of information and, where relevant, information from primary research papers was obtained.

\section{WOUND HEALING AND SCAR FORMATION}

When it comes to deep skin damage, the wound heals in a highly regulated series of dynamic and physiological processes involving various cells, matrix molecules, cytokines, and mediators (5). Wound healing is divided into continuous and overlapping phases including coagulation, inflammatory response phase (the first $48-72 \mathrm{~h}$ after the injury); proliferation phase that includes the formation of extracellular matrix (ECM), angiogenesis, and re-epithelization (days 4-21); and final remodeling or maturation phase, which may last up to a year $(6,7)$. This final regeneration phase results in the formation of a scar with excess collagen and an absence of cutaneous fat and hair follicles (1). Fibrillar collagen, as a main structural component of the ECM, has a crucial role both for the elasticity and the strength of an intact skin and scar tissue (8). Both normal and pathological scars are the result of deposition of collagen type I and III, although collagen synthesis in HSs is two to three times as much as in normotrophic scars (9). Collagen III increases more than type I in the early stages of wound healing but decreases during maturation phase to normal levels (10).

\section{THE CRITICAL ROLE OF MYOFIBROBLASTS AND OTHER ECM COMPONENTS}

It is suggested today that it is the ECM that has the critical role in the scar formation (7). Major players involved in the ECM production are fibroblasts, myofibroblasts, transforming growth factor-beta (TGF- $\beta$ ), proteoglycans-decorin, laminin, and fibronectin, matrix metalloproteinases (MMPs), and bone morphogenetic proteins (BMPs) (7). A key role in the formation of dense collagen matrix during the maturation phase belongs to myofibroblasts originating from fibroblasts, which disappear by apoptosis during normal wound healing when epithelialization occurs (11-13). Various biological properties of both fibroblasts and myofibroblasts have profound impact on the progression and regression of HS. These complex processes are influenced by a signaling network involving different cytokines and growth factors of which are to mention, TGF- $\beta$, epidermal growth factor, platelet-derived growth factor, connective tissue growth factor (CTGF), and vascular endothelial growth factor, which is known as a key factor in angiogenesis essential for wound healing $(14,15)$. The transition from fibroblasts to myofibroblasts expressing $\alpha$-smooth muscle actin (SMA) is influenced by cytokines, previously listed growth factors, especially TGF- $\beta$ whose activity diminishes upon the completion of wound repair, mechanical stress, and cellular fibronectin (16). Myofibroblasts are responsible for the production of type I and III collagen, secretion of profibrotic cytokines, remodeling of an immature ECM, and wound contraction $(12,16,17)$. Additionally, they produce MMPs that catalyze the hydrolysis of the main components of ECM as well as the activity of cytokines and growth factors $(18,19)$. Degradation of fibrillar collagen type I, II, and III is mediated by specific collagenases-1, 2, and 3 (MMP-1, 8, and 13) and gelatinases MMP-2 and MMP-9 (18). MMPs transcription is not only induced by glucocorticosteroids and interleukin (IL)-1 but also regulated by TGF- $\beta$ and insulin-like growth factor- 1 (20, 21). MMPs expression is low in intact skin, but after injuring their expression is increased (19). It has been demonstrated that inhibitors of MMPs slow wound healing in vivo, which indicates that the MMPs are the key regulators of many wound healing processes $(19,22)$. One of the most important MMPs for the formation of fibrous tissue is procollagen $\mathrm{C}$ proteinase-1, BMP1, of the BMP family, which cleaves the carboxylic pro-domain of procollagen I, II, and III to form the insoluble fibrillar collagen of exceptional tensile strength (23-25). Although isolated with other BMP molecules due to their affinity for the heparin, BMP1 does not share the same amino acid sequence homology with other BMPs so it is not an authentic member of the TGF- $\beta$ superfamily. It belongs to the astacin/BMP1/tolloid-like family of zinc MMPs that are fundamental in the development and formation of the ECM $(23,26)$. The importance of BMP1 protein was stressed two decades ago by finding that $B m p 1^{-/-}$mice die shortly after birth from the failure of ventral body wall closure due to abnormal collagen fibrillogenesis (27). To overcome issues of early lethality and functional redundancy in $B m p 1^{-/-}$mice, Muir et al. (28) recently utilized $B T^{K O}$ mice with floxed $B m p 1$ and $T l l 1$ alleles and they came to the findings that loss of the BMP1 proteinase activity resulted in delayed wound healing and significantly thinned and fragile skin with unusually densely grouped collagen fibrils. Their experiment confirmed BMP1-like proteinases as essential proteins to the structure and wound healing of the skin. BMP1 proteinases are crucial for the formation of ECM not only by direct influence to its formation but also indirectly by activating TGF- $\beta$ superfamily members including BMP-2 and BMP-4, 
profibrotic TGF- $\beta 1$, and growth and differentiation factors GDF$8 /-11$ and $\operatorname{IGF}(24,26)$. To date, there are seven different isoforms of the BMP1 protein (25). A substantial progress in the field of fibrotic diseases in human has been made by findings of a number of BMP1 isoforms at the protein level in the circulation of patients with a variety of fibrotic conditions such as chronic kidney disease, acute bone fracture, acute myocardial infarction, but most importantly BMP1-3 isoform known as mammalian tolloid that circulates as an active enzyme in plasma samples of healthy individuals in lower concentrations $(29,30)$. Grgurevic et al. (29) utilized their findings of BMP1-3 protein and tested its effect in rats with chronic kidney disease where administration of rhBMP1-3 increased fibrosis, while BMP1-3 neutralizing antibody reduced it and was associated with low plasma levels of TGF- $\beta 1$, CTGF, and decreased expression of decorin, suggesting that this pathway may be therapeutic target for fibrosis. Decorin is a small leucine-rich proteoglycan produced by myofibroblasts that regulates collagen fibrillogenesis, inhibits the proliferation of fibroblasts, and reduces production of TGF- $\beta 1$ and collagen synthesis in HS fibroblasts whose production is here significantly increased (31-33). Another important proteoglycan that is produced by myofibroblasts, as well as by keratinocytes, endothelial cells, and dermal fibroblasts is cellular fibronectin. It is responsible for the formation of stable collagen I/III fibrillar network through a mechanism involving integrins (34) but it is also vital for regulating the neovascularization of granulation tissue (35).

Most recently, a breakthrough study that identifies another consequential role of myofibroblast was published (36). Although it has been thought that they are differentiated, this study showed that adipocytes may be regenerated from myofibroblasts during wound healing through activation of adipocyte transcription factors expressed during development, triggered by crucial BMP signaling from the actively growing hair follicles. These findings fortify the importance of BMPs during wound healing and scar formation and identify the myofibroblasts as a plastic cell type that may be manipulated to treat scars in humans.

\section{MOLECULAR BIOLOGY OF WOUND HEALING}

Transforming growth factor-beta/Smad signaling has a pivotal role in scar-mediated healing. Both TGF- $\beta 1$ and TGF- $\beta 2$ enhance scarring, i.e., promote fibrosis, whereas TGF- $\beta 3$ reduces scarring; they act through binding to dimeric TGF- $\beta$ receptor complexes $(5,37,38)$. Upon activation, this receptor complex phosphorylates Smad2 and Smad3 proteins, which subsequently form dimers with Smad4 that are able to translocate to nucleus and act as a transcription factor that triggers target gene transcription including collagens I and III (39). TGF- $\beta 1$ and TGF- $\beta 2$ activate this dimeric receptor complex and thereby downstream Smad signaling, whereas TGF- $\beta 3$ is a receptor antagonist that inhibits signal transduction $(20,40)$. Another Smad protein, Smad7, is thought to prevent Smad2/3-receptor interaction and subsequent phosphorylation that makes Smad7 as the negative feedback regulator of this profibrotic signal pathway. Inducing Smad 7 may be promising way to inhibit fibrosis and prevent HS formation (41). Not only that TGF- $\beta$ influences collagen production directly through Smad signaling but also induces Smad 3 to transcribe proteins that activate the Wnt pathway that induces scarring $(37,42)$. It has been experimentally shown that targeting TGF$\beta /$ Smad pathway influences fibroblast proliferation and ECM deposition in HS (40, 43-45).

The local healing process is also influenced by systemic response to injury whereby increases in Th2 and possibly Th3 response cytokines such as IL-2, IL-4, IL-10, and TGF- $\beta$ are found in the circulating lymphocytes in fibrotic conditions (46). Among the other momentous mediators of scarring, there are proinflammatory cytokines IL-6 and IL-8 that enhance scarring, and anti-inflammatory cytokine IL-10 that has the opposite effect (47).

We can say that the key to controlled scarring is a balance between proliferative processes in proliferative phase and degradation and remodeling processes in the early stage of maturation. Thus, the imbalance between proinflammatory, profibrotic growth factors such as TGF- $\beta 1$ and 2 on one side, and antifibrotic factors such as TGF- $\beta 3$ and MMPs on the other side, results in overabundant wound ECM or the formation of a HS. Under certain conditions, primarily due to imbalance of synthesis and degradation of collagen, normal scar is replaced by pathological fibrous tissue with decreased or absent cutaneous fat and hair follicles, containing the same ECM molecules as the tissue they replace, but in different ratios; increased production of collagen type I and III, fibronectin, and laminin, and decreased expression of the hyaluronic acid and decorin $(7,47,48)$.

\section{HSs VERSUS KELOIDS}

Hypertrophic scars mostly develop within 1-3 months after deep skin injury, surgical procedure or burns, in contrast with keloids that may occur up to 12 months after injury or even develop spontaneously (49). Many factors such as age, genetic factors, race, hormone levels, and immunologic responses of the individuals appear to play a role (50-52). Not least important, are the type of injury, wound size and depth, anatomic region, and mechanical tension on the wound (20). Ogawa and Akaishi (51) proposed that all of this mentioned risk factors promote pathological scar formation by inducing endothelial dysfunction (i.e., vascular hyperpermeability) that prolongs and intensifies inflammation, thereby leading to fibroblast dysfunction. The first challenge when dealing with pathological scarring in daily clinical practice is a classification of a scar. Scars can be classified as mature, immature, linear hypertrophic, widespread hypertrophic, minor and major keloid (53). The diagnosis is usually clinical based upon scar appearance, etiology, and growth pattern. Based on current guidelines (54), immature scars are morphologically red and raised, are often associated with slight pain and pruritus, and evolve into mature scars that are pale, soft, narrow, and flat. Linear HSs are those scars that we use as a model of HS type with all of their typical characteristics described in Table 1. Extensive HSs present with irregular, highly erythematous surface and have hardened cord-like appearance. They are usually caused by thermal or chemical burns and lead to functional impairment due to contractures. The terms HS and keloid are often used inconsistently and interchangeably. Although there are clinical similarities 
TABLE 1 | Differences in HSs and keloids.

\begin{tabular}{|c|c|}
\hline HSs & Keloids \\
\hline Frequent incidence & Rare incidence \\
\hline Posttraumatic & Posttraumatic or spontaneous \\
\hline Develop soon after surgery & May not begin for many months \\
\hline Usually subside with time & Rarely subside with time \\
\hline Remain within the wound boundaries & Spread outside the wound boundaries \\
\hline $\begin{array}{l}\text { No predominant anatomical site but } \\
\text { often occur when skin creases are at } \\
\text { right angle or when scars cross joints }\end{array}$ & $\begin{array}{l}\text { Predominant anatomical sites (chest, } \\
\text { shoulders, upper back, earlobes, } \\
\text { posterior neck, knees) }\end{array}$ \\
\hline Pruritic, rarely painful & Pruritic, painful \\
\hline Less association with phototype & More common in darker skin types \\
\hline Genetic predisposition & Less genetic predisposition \\
\hline $\begin{array}{l}\text { Improve with appropriate surgery, low } \\
\text { recurrence rate }\end{array}$ & $\begin{array}{l}\text { Often worsened by surgery, high } \\
\text { recurrence rate }\end{array}$ \\
\hline $\begin{array}{l}\text { Increase collagen synthesis; } 7 \text { times } \\
\text { higher than normal }\end{array}$ & $\begin{array}{l}\text { Increase collagen synthesis; } 20 \text { times } \\
\text { higher than normal }\end{array}$ \\
\hline Collagen type I < III & Collagen type ||$l \mid$ \\
\hline $\begin{array}{l}\text { Fine collagen fibers organized into } \\
\text { nodules, predominantly parallel }\end{array}$ & $\begin{array}{l}\text { Large, thick collagen fibers, closely } \\
\text { packed random to epidermis }\end{array}$ \\
\hline Flatter collagen fibers in wavy pattern & Fibers lie haphazardly \\
\hline High collagen cross-link & $\begin{array}{l}\text { Collagen cross-link twice higher than } \\
\text { in HS }\end{array}$ \\
\hline Myofibroblasts that express $\alpha$-SMA & Absence of myofibroblasts \\
\hline $\begin{array}{l}\text { Fibroblasts: } \uparrow \text { cell number, } \uparrow \uparrow \text { proliferation, } \\
\downarrow \downarrow \text { apoptosis, } \uparrow \uparrow \text { collagen I }\end{array}$ & $\uparrow \uparrow$ proliferation, $\uparrow \uparrow$ collagen I \\
\hline$\uparrow \uparrow T G F-\beta 1, \uparrow T G F-\beta 2, \downarrow \downarrow T G F-\beta 3$ & $\uparrow \uparrow T G F-\beta 1, \uparrow \uparrow T G F-\beta 2, \downarrow \downarrow T G F-\beta 3$ \\
\hline
\end{tabular}

$\uparrow$, increase; $\downarrow$, decrease; SMA, smooth muscle actin; TGF- $\beta$, transforming growth factor-beta; HSs, hypertrophic scars.

between two of them, there are many pathological and biochemical differences that suggest that these entities are distinctive $(55,56)$. HSs are characterized as raised, pink or red scars, sometimes pruritic and painful, within the margins of the original wound (Figures 1A,B), that develop soon after surgery and usually subside with time as opposed to keloids (Figures 1C,D) that spread out of the margins of the wound, may develop months after the trauma, and continue to evolve over time without regression $(49,57)$. HSs and keloids are also distinguishable based on their histologic characteristics. HSs contain primarily type III collagen bundles that are oriented parallel to the epidermal surface arranged in a wavy pattern with abundant nodules containing myofibroblasts expressing $\alpha$-SMA and large extracellular collagen filaments. In contrast, keloid tissue is composed of disorganized type I and III thick, eosinophilic collagen bundles that appear randomly oriented to the epithelial surface with no nodules or excess myofibroblasts $(9,56,58,59)$. To note is that HSs go through a remodeling phase, while keloids do not enter this final wound healing phase. Remodeling happens due to the presence of myofibroblasts in HSs that account for various processes during this phase and contraction of the wound. HS myofibroblasts are less responsive to apoptotic signals and produce more ECM components especially type I collagen, whose synthesis is seven times higher than normal (56). Treatment of HS is demanding, often painful, enduring, and mostly unsatisfactory (3). Due to the similar underlying pathophysiology, HSs and keloids may respond to the same treatment modalities. However, HSs are often more responsive and less prone to recurrence, which makes them therapeutically less challenging. To date, multiple invasive and non-invasive therapies have been used and proposed, but none of

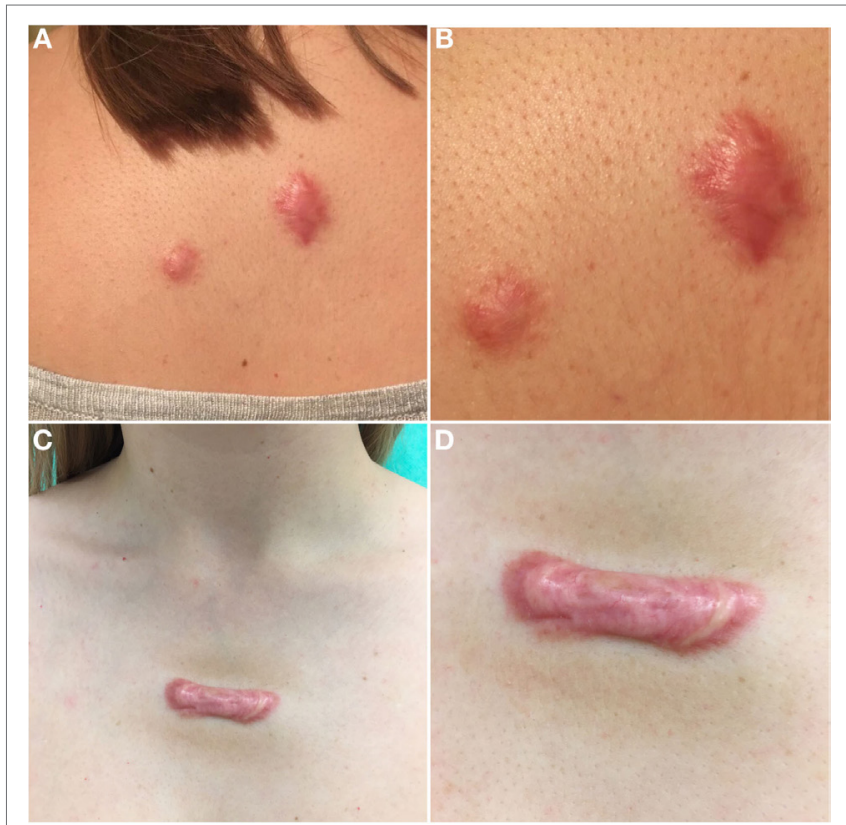

FIGURE 1 | Clinical appearance of hypertrophic scar (HS) and keloid. (A) HSs on upper back that developed after excision of dermal nevi. (B) Close-up of HSs. (C) Chest of patient showing keloid developed spontaneously. (D) Close-up of keloid.

these has been adequately evaluated in high-quality studies (60). Management of HS has transitioned from invasive methods to intralesional and topical therapies that act at a cellular level (61).

\section{PREVENTION IS THE KEY}

The most significant segment of an approach to hypertrophic scarring is its prevention. Before an elective surgery doctors should be informed if their patients have had previous problems with scarring. When performing surgery, incisions should follow Langer's lines that correspond to the natural orientation of collagen fibers in the dermis and are parallel to the direction of the underlying muscle fibers (62). Incisions made parallel to Langer's lines are known to heal better and produce less scarring than those that cut across (63). Also, it is important that all the incisions are closed with minimal tension that they do not cross joint spaces and that midchest incisions are avoided whenever possible (49). For the non-surgical wounds following trauma, it is crucial to debride contaminated ones and remove foreign bodies to minimize the inflammatory response; also, to promote adequate wound management with regular dressing changes to provide wound coverage and moist healing $(57,64)$. All the predisposed individuals presenting with any inflammatory skin problems as acne or deeper skin infections should be treated correspondingly to minimize inflammation (65). If we cannot avoid surgery in patients at a high risk of HS, immediate silicone-based products such as gels or sheeting with or without corticosteroid injections should be administered. Silicone sheeting is considered as the internationally recommended first-line option of scar 
TABLE 2 | Treatment options for hypertrophic scars.

Therapeutic modality Mechanism of action (application)

Topical agents

Silicone gel

Silicone sheet

Onion extract creams

Imiquimod 5\%

cream (alternate

night applications for

2 months after surgery)

\section{Intralesional injections}

Corticosteroid

injections; TAC

(10-40 mg/mL into

papillary dermis every

2-4 weeks until scar is

flattened)

\section{5-FU 50 mg/mL}

Weekly intervals, 2- or 4-week intervals; 3-6 injections

TAC:5-FU 4:45 mg/mL (1:9); 10:37.5 (1:3)

Interferon therapy (INF-

$\alpha, \beta, \gamma)$

INF- $\alpha 2 b-3$ times

weekly

INF- $\gamma$-intralesionally

once per week up to

a dosage of $0.05 \mathrm{mg}$

for 10 weeks or

0.01-0.1 mg 3 times a

week/3 week
Optimal occlusion and hydration of the stratum corneum; $\downarrow$ TEWL, subsequent $\downarrow c y t o k i n e-m e d i a t e d$ signaling from keratinocytes to dermal fibroblasts. Gentle reduction of tension. Static electricity

Anti-inflammatory effect, bactericidal, and inhibit fibroblast proliferation

Flavonoids (quercetin and kaempferol) in onion extract play the main role in reducing scar formation through inhibition of fibroblast proliferation

Induction of MMP-1

Inhibition of TGF- $\beta 1$ and $-\beta 2$ and SMAD proteins

Improve color, stiffness, and irregularity of the scar

$\downarrow T N F-\alpha$, INF- $\alpha$, IL-1, IL-4, IL-5, IL-6, IL-8, IL-12, alters the expression of markers for apoptosis; improved scar quality
Advantages

Disadvantages

Comment

Reference
Easy to use, Sheets need to be can be applied washed daily. Risk at home of infection

Non-invasive, 6-12 months safe, tolerated constant wear to by children

Multiple

formulations

and formats

available

Well-tolerated

preventative

treatment

initiation achieve optimum results. Expensive
Should be avoided on open wounds

$(66,81-83)$ in hot climates

For prevention of HS; treatment can be

Poor study design

Onion extract therapy should be used in combination with an occlusive silicon dressing to achieve a satisfying decrease in scar thickness. Now available in form of an occlusive patch that has dual effect
Gel preferred over sheets on visible areas and considered as additional therapy in active HS
Minimal recurrence
Vasoconstrictive, anti-inflammatory, immunosuppressive effect. Inhibition of keratinocyte and fibroblast proliferation, glycosaminoglycan synthesis. $\downarrow$ MMPs inhibitors

Cell proliferation inhibition, $\uparrow$ fibroblast apoptosis, collagen-1 suppression, MMP-2 induction
Inhibit the formation of HS. Reduce pain and pruritus

No systemic side effects

No serious toxic effects Dermal cream containing liposomeencapsulated IFN- $\alpha 2 b$
Multiple injections administered by a clinician. Discomfort, painful. Skin atrophy, hypopigmentation

Pain, purpura, burning sensation, transient hyperpigmentation

Risk of ulcerations in dark-skinned patients

Painful when administered intralesionally. Flu-like symptoms. Expensive telangiectasia,
Monotherapy or in combination with two 15-s cryotherapy cycles prior to application to facilitate the injection through the development of edema, to reduce the pain and improve the result. Clinical benefit of adding 5-FU. TAC treatment can be performed on the day of surgery to prevent the formation of HS in patients at risk

Alone or with corticosteroids (more effective and less painful); combination of TAC (40 mg/ $\mathrm{mL})$ and 5-FU (50 mg/mL) (1:3) injected intralesionally once weekly for 2 months superior to exclusive weekly injection of TAC $40 \mathrm{mg} / \mathrm{mL}$

The addition of the pulsed-dye laser treatments is to be most effective

Not recommended during pregnancy, bone marrow suppression, anemia, etc. At the start of treatment as well as after four injections a blood count should be done

Concept of the early topical use of this antifibrogenic agent for the treatment of dermal fibroproliferative disorders
(90-92) pathway), $\downarrow$ ECM production, $\downarrow$ collagen I and III synthesis 
TABLE 2 | Continued

\begin{tabular}{|c|c|c|c|c|c|}
\hline $\begin{array}{l}\text { Therapeutic modality } \\
\text { (application) }\end{array}$ & Mechanism of action & Advantages & Disadvantages & Comment & Reference \\
\hline $\begin{array}{l}\text { Bleomycin [intralesional } \\
\text { multiple injections } \\
0.1 \mathrm{~mL}(1.5 \mathrm{IU} / \mathrm{mL}) \text { at } \\
\text { a max dose of } 6 \mathrm{~mL} \text {, } \\
2-6 \text { sessions within a } \\
\text { month] }\end{array}$ & $\begin{array}{l}\text { Induces apoptosis, } \downarrow \text { TGF- } \beta 1-\downarrow \\
\text { collagen synthesis } \\
\downarrow \text { Height, pliability as well as reduction in } \\
\text { erythema, pruritus, and pain }\end{array}$ & $\begin{array}{l}\text { Easy to } \\
\text { administer, } \\
\text { cheap, high } \\
\text { regression } \\
\text { rate, minimum } \\
\text { complication } \\
\text { and recurrence }\end{array}$ & $\begin{array}{l}\text { Sporadically, } \\
\text { development of } \\
\text { depigmentation } \\
\text { and dermal } \\
\text { atrophy has been } \\
\text { noted. Systemic } \\
\text { toxic effects } \\
\text { of intralesional } \\
\text { injections appear to } \\
\text { be rare }\end{array}$ & $\begin{array}{l}\text { Considerable success. Due to its toxicity, } \\
\text { clinicians are encouraged to be aware of } \\
\text { associated potential problems } \\
\text { Larger scale prospective studies needed }\end{array}$ & $(98-100)$ \\
\hline $\begin{array}{l}\text { Verapamil (intralesional } \\
2.5 \mathrm{mg} / \mathrm{mL} \text { ) }\end{array}$ & $\begin{array}{l}\text { Stimulates procollagenase synthesis- } \\
\downarrow \text { collagen synthesis, } \uparrow \text { collagen } \\
\text { breakdown, } \downarrow \text { scar elevation, vascularity, } \\
\text { pliability }\end{array}$ & $\begin{array}{l}\text { Low cost, } \\
\text { fewer adverse } \\
\text { effects }\end{array}$ & & $\begin{array}{l}\text { Monotherapy or as adjuvant therapy after } \\
\text { excision with or without silicone }\end{array}$ & $(101,102)$ \\
\hline $\begin{array}{l}\text { Botulinum toxin } \mathrm{A} \\
\text { Intralesional injections } \\
(2.5 \mathrm{U} / \mathrm{mL} \text { at } 1 \text {-month } \\
\text { intervals) for } 3 \text { months } \\
4-7 \text { days before the } \\
\text { surgery }\end{array}$ & $\begin{array}{l}\downarrow \text { Erythema, itching sensation, and } \\
\text { pliability } \\
\text { Chemoimmobilization-temporary } \\
\text { muscular paralysis, } \downarrow \text { tension vectors } \\
\text { on wound edges, enhances scarring of } \\
\text { facial wounds. } \downarrow \text { CTGF, } \downarrow \text { TGF- } \alpha 1\end{array}$ & $\begin{array}{l}\text { Acceptable for } \\
\text { both doctors } \\
\text { and patients } \\
\text { Improvement } \\
\text { and the rate } \\
\text { of therapeutic } \\
\text { satisfaction is } \\
\text { very high }\end{array}$ & Expensive & $\begin{array}{l}\text { Beneficial for use in young patients for wounds } \\
\text { without tissue loss, lying perpendicular to the } \\
\text { reduced tension lines of the skin of the face } \\
\text { Larger, randomized, control studies are } \\
\text { warranted }\end{array}$ & $(103-105)$ \\
\hline $\begin{array}{l}\text { TGF- } \beta \text { and isomers } \\
\text { avotermin }(\mathrm{hrTGF} \beta-3) \\
(50-500 \mathrm{ng} / 100 \mu \mathrm{g} \\
\text { per linear centimeter } \\
\text { of wound margin given } \\
\text { once) }\end{array}$ & $\begin{array}{l}\text { Significant improvement in scar } \\
\text { appearance }\end{array}$ & $\begin{array}{l}\text { Safe and } \\
\text { tolerable }\end{array}$ & & $\begin{array}{l}\text { Prevention or reduction of scarring following } \\
\text { surgery. Ongoing clinical trials }\end{array}$ & $(106-108)$ \\
\hline Mannose-6-phosphate & $\begin{array}{l}\text { Reduction of fibrosis by inhibiting } \\
\text { TGF- } \beta 1 \text { and } 2 \text { activation }\end{array}$ & $\begin{array}{l}\text { Safe and } \\
\text { tolerable }\end{array}$ & & Clinical trial & \\
\hline
\end{tabular}

\section{Other current therapeutic options}

Compression therapy

Elastic bandages or pressure garments (20-40 mmHg)
Cryotherapy (monthly sessions)

Surgery Z- or W-plasty, grafts, or local skin flaps
Reduction in scar thickness

MMP-9 activation; prostanglandin E2 $\uparrow$, subsequent $\uparrow$ collagenases. Pressureinduced hypoxic effects leading to collagen and fibroblast degeneration
Non-invasive. Expensive Can be applied (custom made). at home

Recommended for special locations (e.g., on the ear)

Induce vascular damage that may lead to anoxia and ultimately tissue necrosis

$\downarrow$ Scar volume, hardness, elevation, erythema

Interrupt the circle between scar tension and ensuing further thickening of the scar due to permanently stimulated ECM production
Easy to perform, low cost

nec

Treatment of postburn scars and scars in children. Applied when wound is closed. Can beneficial effects remain unproven

\section{be used in combination with silicones. The} (cause discomfort 6-24 months constant wear to achieve optimum results). Sweating and swelling of the limbs; dermatitis, pressure erosions, and ulcerations can develop

Hypopigmentation, pain, moderate atrophy, protracted healing time

Invasive. Risk of recurrence
Z-plasty option for burns. Immediate postsurgical additional treatment needed to prevent regrowth

First-line treatment if disabling scar contractures are present. Surgical therapy of $\mathrm{HS}$ without tension and without contractures, present less than 1 year, is not recommended
Useful on small lesions. Easy to perform. New intralesional cryoneedles have shown $\uparrow$ efficacy

$(95,114)$ 
TABLE 2 | Continued

\begin{tabular}{|c|c|c|c|c|c|}
\hline $\begin{array}{l}\text { Therapeutic modality } \\
\text { (application) }\end{array}$ & Mechanism of action & Advantages & Disadvantages & Comment & Reference \\
\hline \multicolumn{6}{|l|}{ Laser procedures } \\
\hline $\begin{array}{l}\text { Ablative lasers }\left(\mathrm{CO}_{2}\right. \\
\text { Er:YAG) }\end{array}$ & $\begin{array}{l}\text { Induction of capillary } \\
\text { destruction-generates } \\
\text { hypoxemia-alters local collagen } \\
\text { production. } \uparrow M M P s \\
\text { Improvement of pigmentation, } \\
\text { vascularity, pliability, and scar height }\end{array}$ & $\begin{array}{l}\text { Reach greater } \\
\text { depths than } \\
\text { a pulsed-dye } \\
\text { laser }\end{array}$ & $\begin{array}{l}\text { Mild side effects } \\
\text { that include a } \\
\text { prickling sensation } \\
\text { during treatment } \\
\text { and post-treatment } \\
\text { erythema } \\
\text { Erosions, weeping, } \\
\text { and crusting can } \\
\text { occur }\end{array}$ & $\begin{array}{l}\text { For inactive HS with height differences, bridge } \\
\text { or contracture formation. } \mathrm{CO}_{2} \text { shows superior } \\
\text { effectiveness. Fractional } \mathrm{CO}_{2} \text { is option in } \\
\text { postburn HS }\end{array}$ & $(116)$ \\
\hline $\begin{array}{l}\text { Non-ablative lasers; } \\
\text { pulsed-dye laser } \\
585 / 595 \text { nm }\end{array}$ & $\begin{array}{l}\text { Induction of selective capillary } \\
\text { destruction-generates } \\
\text { hypoxemia-alters local collagen } \\
\text { production. } \uparrow \text { MMPs }\end{array}$ & $\begin{array}{l}\text { Minimal } \\
\text { side effects, } \\
\text { purpura usually } \\
\text { persisting for } \\
7-14 \text { days }\end{array}$ & $\begin{array}{l}\text { Expensive. } \\
\text { Specialist } \\
\text { referral needed. } \\
\text { Vascular-specific }\end{array}$ & $\begin{array}{l}\text { Excellent first-line treatment, preventive } \\
\text { strategy for HS, reduce erythema primarily }\end{array}$ & $\begin{array}{c}(98,117 \\
118)\end{array}$ \\
\hline $\begin{array}{l}\text { Gold standard: } \\
\text { application on the day } \\
\text { of suture removal, } \\
44.5 \mathrm{~J} / \mathrm{cm}^{2} \text { about } \\
1.5-2 \text { ms (every } \\
3-4 \text { weeks) }\end{array}$ & $\begin{array}{l}\text { Reducing erythema, pruritus, pliability, } \\
\text { improving skin texture }\end{array}$ & $\begin{array}{l}\text { Depending } \\
\text { on the energy } \\
\text { density } \\
\text { employed, } \\
\text { vesicles and } \\
\text { crusts may } \\
\text { occur }\end{array}$ & & Do not appear to be adequate for thick HS & \\
\hline
\end{tabular}

$\uparrow$, increase; $\downarrow$, decrease; TEWL, transepidermal water loss; ECM, extracellular matrix; MMP, matrix metalloproteinase; HS, hypertrophic scar; CTGF, connective tissue growth factor; IL, interleukin; 5-FU, 5-fluorouracil; TAC, triamcinolone acetonide; TGF- $\beta$, transforming growth factor-beta.

management, which should be used after the wound has fully epithelialized (66). They should be applied for 12-24 h/day with daily washing for at least 2 months up to 1-2 years (54). Silicone gel is often preferred to sheeting from the perspective of ease of application and patient compliance especially when applied on the face, mobile areas, and in patients living in humid climates due to sheeting dislodgment. Silicone gel has been shown not to be inferior to sheeting in improving objective and subjective characteristics of scars, but it is superior in the ease of use (67). However, for extensive hypertrophic burn scars pressure garments still represent the first-line prophylactic therapy (68). The type of preventive scar measure that would be applied to a patient depends on the individual's risk factors and his/her esthetic concerns. After trauma, in patients with moderate risk of scarring it is advised to apply silicone gels or dressings as preferred therapy, with topical products containing onion extracts or hypoallergenic adhesive tape for a few weeks after surgery as acceptable alternatives (69). In low-risk patients, we should just monitor wounds and prescribe silicone sheeting products for worried individuals (70). Other general measures to prevent HS formation include compression therapy, the use of moisturizers, manual massage, and strict UV photoprotection measures during scar formation and maturation phase to avoid hyperpigmentation $(71,72)$. As a rule, scars should be reevaluated $4-8$ weeks after surgery to determine further management.

\section{SCAR EVALUATION}

If eventually scar forms, regardless of whether or not prophylactic measures were applied, it should be evaluated. When assessing scars, their size, color, contour, height (thickness), surface area, surface texture, pliability, location, and subjective symptoms such as itching and pain, and also patient's perception should be taken into account. It has been indicated that this subjective component of the patient's view of the scar is as important as objective aspect and it may be very influential in determining the patient's quality of life $(73,74)$. Assessment of the scars is a frequent topic of discussion among clinicians because there is no generally accepted evaluation tool, although various ones have been proposed (75-77). None of these, however, seem suitable as a stand-alone tool, suggesting that combination of objective imaging tools and scar scales and questionnaires may be justified to achieve comprehensive documentation in everyday clinical practice (78).

\section{CURRENT APPROACH TO HS MANAGEMENT}

When dealing with future scar reduction modalities, it is of great importance for clinicians to not only discuss with patients their concerns, needs, and expectations but also to educate them about possible treatment options and their outcomes. The approach to treatment and its goals should be set for the individual patient based upon scar evaluation, patients's characteristics, and expectations in order to reduce the scar volume, minimize subjective symptoms, i.e., pain and pruritus, and to improve function and esthetic appearance. As we have mentioned earlier, HSs are characterized by their ability to potentially regress over time. However, this maturation process is slow. So, the goal of the treatment is to stimulate this process to improve objective and subjective symptoms. According to updated international 
clinical recommendations on scar management (54) and others that adopted them (70), when treating linear or small HS resulting from trauma or surgery, silicone gel sheeting and topical onion extracts are considered as the first-line therapy. If there is no improvement within a month, we can start second-line therapy that is intralesional corticosteroid injections-triamcinolone acetonide $10-40 \mathrm{mg} / \mathrm{mL}$ with or without cryosurgery at monthly intervals for 3-4 months. Second-line therapy also includes laser therapy (pulsed-dye laser or fractional laser) and surgical excision in combination with postoperative silicone sheeting or postoperative intralesional corticosteroid/5-fluorouracil (5-FU) injections (79). Corticosteroids suppress healing and abnormal scarring by three mechanisms: vasoconstriction, anti-inflammatory and immunosuppressive effect, and inhibition of keratinocyte and fibroblast proliferation (80). When facing extensive HSs as are the postburn ones, of great importance is acute treatment at specialized burn centers where debridement and possible skin grafting are performed. Afterward, first-line therapy, as in linear HSs, includes silicone sheeting or gel and topical onion extracts. First-line also includes pressure garments that are also the first-line prophylactic therapy measure for postburn scars. Current international guidelines recommend ablative fractional laser, $\mathrm{CO}_{2}$ laser, as promising second-line therapy for this extensive HSs but also for inactive, linear HSs. The abovementioned commonly used and innovative scar-reducing modalities are presented in detail in Table 2.

\section{CONCLUSION}

Scarring and its accompanying esthetic, functional, and psychological sequelae still pose major challenges. To date, there is no satisfactory prevention or treatment option for HS, which is mostly due to not completely comprehending the mechanisms underlying their formation. A predominant role in hypertrophic scarring prevention and treatment still maintain silicone sheeting or gel. The efficacy and safety of this gold-standard, non-invasive therapy has been demonstrated in many clinical studies, but to date, exact mechanisms by which they improve HS are yet to be fully agreed upon. Second most validated and more specialized scar treatment is intralesional corticosteroid injections, especially in combination with other therapeutic modalities like 5-FU, which augment the result and reduce the side effects of corticosteroids. Current therapeutic approaches with their empirical effects are unreliable and unpredictable. Therefore, there is an unmet need for an effective, targeted therapy and prevention, which would be based on an action or a modulation of a specific factor with clarified mechanism of action that has a beneficial effect on wound healing. As the ECM is involved in cellular and extracellular events that lead to pathological scarring, targeting its components mostly by regulating BMPs may throw up new therapeutic approach for reduction or prevention of pathological scarring or HSs with functionally and cosmetically acceptable outcome.

\section{AUTHOR CONTRIBUTIONS}

$\mathrm{ZM}$ and $\mathrm{AJ}$ performed the literature review and wrote the manuscript. ID-Č participated in literature search and review. KK and $\mathrm{RC}$ provided assistance in preparation of the tables. LG and BM revised the manuscript critically. All authors read and approved the final version of the submitted manuscript.

\section{REFERENCES}

1. Borthwick LA, Wynn TA, Fisher AJ. Cytokine mediated tissue fibrosis. Biochim Biophys Acta (2013) 1832:1049-60. doi:10.1016/j.bbadis.2012.09.014

2. Sen CK, Gordillo GM, Roy S, Kirsner R, Lambert L, Hunt TK, et al. Human skin wounds: a major and snowballing threat to public health and the economy. WoundRepairRegen(2009) 17:763-71.doi:10.1111/j.1524-475X.2009.00543.x

3. Gauglitz GG, Korting HC, Pavicic T, Ruzicka T, Jeschke MG. Hypertrophic scarring and keloids: pathomechanisms and current and emerging treatment strategies. Mol Med (2011) 17:113-25. doi:10.2119/molmed.2009.00153

4. Bock O, Schmid-Ott G, Malewski P, Mrowietz U. Quality of life of patients with keloid and hypertrophic scarring. Arch Dermatol Res (2006) 297:433-8. doi:10.1007/s00403-006-0651-7

5. Werner S, Grose R. Regulation of wound healing by growth factors and cytokines. Physiol Rev (2003) 83:835-70. doi:10.1152/physrev.00031.2002

6. Li J, Chen J, Kirsner R. Pathophysiology of acute wound healing. Clin Dermatol (2007) 25:9-18. doi:10.1016/j.clindermatol.2006.09.007

7. Xue M, Jackson CJ. Extracellular matrix reorganization during wound healing and its impact on abnormal scarring. Adv Wound Care (New Rochelle) (2015) 4:119-36. doi:10.1089/wound.2013.0485

8. Kadler KE, Holmes DF, Trotter JA, Chapman JA. Collagen fibril formation. Biochem J (1996) 316:1-11. doi:10.1042/bj3160001

9. Linares HA, Kischer CW, Dobrkovsky M, Larson DL. The histiotypic organization of the hypertrophic scar in humans. J Invest Dermatol (1972) 59:323-31. doi:10.1111/1523-1747.ep12627386

10. Gay S, Vijanto J, Raekallio J, Penttinen R. Collagen types in early phases of wound healing in children. Acta Chir Scand (1977) 144:205-11.

11. Sarrazy V, Billet F, Micallef L, Coulomb B, Desmouliere A. Mechanisms of pathological scarring: role of myofibroblasts and current developments.

Wound Repair Regen (2011) 19:s10-5. doi:10.1111/j.1524-475X.2011. 00708.x

12. Hinz B. The role of myofibroblasts in wound healing. Curr Res Transl Med (2016) 64:171-7. doi:10.1016/j.retram.2016.09.003

13. Micallef L, Vedrenne N, Billet F, Coulomb B, Darby IA, Desmouliere A. The myofibroblast, multiple origins for major roles in normal and pathological tissue repair. Fibrogenesis Tissue Repair (2012) 5:S5. doi:10.1186/17551536-5-s1-s5

14. Lian N, Li T. Growth factor pathways in hypertrophic scars: molecular pathogenesis and therapeutic implications. Biomed Pharmacother (2016) 84:42-50. doi:10.1016/j.biopha.2016.09.010

15. DiPietro LA. Angiogenesis and wound repair: when enough is enough. J Leukoc Biol (2016) 100:979-84. doi:10.1189/jlb.4MR0316-102R

16. Gabbiani G. The myofibroblast in wound healing and fibrocontractive diseases. J Pathol (2003) 200:500-3. doi:10.1002/path.1427

17. Bochaton-Piallat ML, Gabbiani G, Hinz B. The myofibroblast in wound healing and fibrosis: answered and unanswered questions. F1000Research (2016) 5:752. doi:10.12688/f1000research.8190.1

18. Knapinska A, Fields GB. Chemical biology for understanding matrix metalloproteinase function. Chembiochem (2012) 13:2002-20. doi:10.1002/ cbic. 201200298

19. Gill SE, Parks WC. Metalloproteinases and their inhibitors: regulators of wound healing. Int J Biochem Cell Biol (2008) 40:1334-47. doi:10.1016/ j.biocel.2007.10.024

20. Niessen FB, Spauwen PH, Schalkwijk J, Kon M. On the nature of hypertrophic scars and keloids: a review. Plast Reconstr Surg (1999) 104:1435-58. doi:10.1097/00006534-199910000-00031

21. Ghahary A, Shen YJ, Nedelec B, Wang R, Scott PG, Tredget EE. Collagenase production is lower in post-burn hypertrophic scar fibroblasts than in normal 
fibroblasts and is reduced by insulin-like growth factor-1. J Invest Dermatol (1996) 106:476-81. doi:10.1111/1523-1747.ep12343658

22. Gutierrez-Fernandez A, Inada M, Balbin M, Fueyo A, Pitiot AS, Astudillo A, et al. Increased inflammation delays wound healing in mice deficient in collagenase-2 (MMP-8). FASEB J (2007) 21:2580-91. doi:10.1096/f.06$7860 \mathrm{com}$

23. Hopkins DR, Keles S, Greenspan DS. The bone morphogenetic protein 1/Tolloid-like metalloproteinases. Matrix Biol (2007) 26:508-23. doi:10.1016/j.matbio.2007.05.004

24. Vadon-Le Goff S, Hulmes DJ, Moali C. BMP-1/tolloid-like proteinases synchronize matrix assembly with growth factor activation to promote morphogenesis and tissue remodeling. Matrix Biol (2015) 4(4-46):14-23. doi:10.1016/j.matbio.2015.02.006

25. Kessler E, Takahara K, Biniaminov L, Brusel M, Greenspan DS. Bone morphogenetic protein-1: the type I procollagen C-proteinase. Science (1996) 271:360-2. doi:10.1126/science.271.5247.360

26. Ge G, Greenspan DS. Developmental roles of the BMP1/TLD metalloproteinases. Birth Defects Res C Embryo Today (2006) 78:47-68. doi:10.1002/ bdrc. 20060

27. Suzuki N, Labosky PA, Furuta Y, Hargett L, Dunn R, Fogo AB, et al. Failure of ventralbody wall closure in mouse embryoslacking a procollagen C-proteinase encoded by Bmp1, a mammalian gene related to Drosophila tolloid. Development (1996) 122:3587-95.

28. Muir AM, Massoudi D, Nguyen N, Keene DR, Lee S-J, Birk DE, et al. BMP1like proteinases are essential to the structure and wound healing of skin. Matrix Biol (2016) 56:114-31. doi:10.1016/j.matbio.2016.06.004

29. Grgurevic L, Macek B, Healy DR, Brault AL, Erjavec I, Cipcic A, et al. Circulating bone morphogenetic protein 1-3 isoform increases renal fibrosis. J Am Soc Nephrol (2011) 22:681-92. doi:10.1681/asn.2010070722

30. Grgurevic L, Macek B, Mercep M, Jelic M, Smoljanovic T, Erjavec I, et al. Bone morphogenetic protein (BMP)1-3 enhances bone repair. Biochem Biophys Res Commun (2011) 408:25-31. doi:10.1016/j.bbrc.2011.03.109

31. Zhang Z, Li XJ, Liu Y, Zhang X, Li YY, Xu WS. Recombinant human decorin inhibits cell proliferation and downregulates TGF-betal production in hypertrophic scar fibroblasts. Burns (2007) 33:634-41. doi:10.1016/j. burns.2006.08.018

32. Zhang Z, Garron TM, Li XJ, Liu Y, Zhang X, Li YY, et al. Recombinant human decorin inhibits TGF-beta1-induced contraction of collagen lattice by hypertrophic scar fibroblasts. Burns (2009) 35:527-37. doi:10.1016/j. burns.2008.08.021

33. Wang P, Liu X, Xu P, Lu J, Wang R, Mu W. Decorin reduces hypertrophic scarring through inhibition of the TGF-betal/Smad signaling pathway in a rat osteomyelitis model. Exp Ther Med (2016) 12:2102-8. doi:10.3892/ etm.2016.3591

34. Zoppi N, Gardella R, De Paepe A, Barlati S, Colombi M. Human fibroblasts with mutations in COL5A1 and COL3A1 genes do not organize collagens and fibronectin in the extracellular matrix, down-regulate alpha2betal integrin, and recruit alphavbeta3 instead of alpha5betal integrin. J Biol Chem (2004) 279:18157-68. doi:10.1074/jbc.M312609200

35. To WS, Midwood KS. Plasma and cellular fibronectin: distinct and independent functions during tissue repair. Fibrogenesis Tissue Repair (2011) 4:21. doi:10.1186/1755-1536-4-21

36. Plikus MV, Guerrero-Juarez CF, Ito M, Li YR, Dedhia PH, Zheng Y, et al. Regeneration of fat cells from myofibroblasts during wound healing. Science (2017) 355:748-52. doi:10.1126/science.aai8792

37. Sun Q, Guo S, Wang CC, Sun X, Wang D, Xu N, et al. Cross-talk between TGF-beta/Smad pathway and Wnt/beta-catenin pathway in pathological scar formation. Int J Clin Exp Pathol (2015) 8(6):7631-9.

38. Arno AI, Gauglitz GG, Barret JP, Jeschke MG. Up-to-date approach to manage keloids and hypertrophic scars: a useful guide. Burns (2014) 40:1255-66. doi:10.1016/j.burns.2014.02.011

39. Pakyari M, Farrokhi A, Maharlooei MK, Ghahary A. Critical role of transforming growth factor beta in different phases of wound healing. Adv Wound Care (New Rochelle) (2013) 2:215-24. doi:10.1089/wound.2012.0406

40. Shah M, Foreman DM, Ferguson MW. Neutralisation of TGF-beta 1 and TGF-beta 2 or exogenous addition of TGF-beta 3 to cutaneous rat wounds reduces scarring. J Cell Sci (1995) 108:985-1002.

41. Li N, Kong M, Ma T, Gao W, Ma S. Uighur medicine abnormal savda munzip (ASMq) suppresses expression of collagen and TGF-betal with concomitant induce Smad7 in human hypertrophic scar fibroblasts. Int J Clin Exp Med (2015) 8:8551-60.

42. Roberts AB, Russo A, Felici A, Flanders KC. Smad3: a key player in pathogenetic mechanisms dependent on TGF-beta. Ann N Y Acad Sci (2003) 995:1-10. doi:10.1111/j.1749-6632.2003.tb03205.x

43. Bai X, He T, Liu J, Wang Y, Fan L, Tao K, et al. Loureirin B inhibits fibroblast proliferation and extracellular matrix deposition in hypertrophic scar via TGF-beta/Smad pathway. Exp Dermatol (2015) 24:355-60. doi:10.1111/ exd.12665

44. Bai XZ, Liu JQ, Yang LL, Fan L, He T, Su LL, et al. Identification of sirtuin 1 as a promising therapeutic target for hypertrophic scars. Br J Pharmacol (2016) 173:1589-601. doi:10.1111/bph.13460

45. Zhao J, Shu B, Chen L, Tang J, Zhang L, Xie J, et al. Prostaglandin E2 inhibits collagen synthesis in dermal fibroblasts and prevents hypertrophic scar formation in vivo. Exp Dermatol (2016) 25:604-10. doi:10.1111/exd.13014

46. Armour A, Scott PG, Tredget EE. Cellular and molecular pathology of HTS: basis for treatment. Wound Repair Regen (2007) 15:S6-17. doi:10.1111/j.1524-475X.2007.00219.x

47. Profyris C, Tziotzios C, Do Vale I. Cutaneous scarring: pathophysiology, molecular mechanisms, and scar reduction therapeutics Part I. The molecular basis of scar formation. J Am Acad Dermatol (2012) 66:1-10; quiz 1-2. doi:10.1016/j.jaad.2011.05.055

48. Sidgwick GP, Bayat A. Extracellular matrix molecules implicated in hypertrophic and keloid scarring. J Eur Acad Dermatol Venereol (2012) 26:141-52. doi:10.1111/j.1468-3083.2011.04200.x

49. WolframD,TzankovA,PülzlP,Piza-KatzerH.Hypertrophicscarsandkeloids-a review of their pathophysiology, risk factors, and therapeutic management. Dermatol Surg (2009) 35:171-81. doi:10.1111/j.1524-4725.2008.34406.x

50. English RS, Shenefelt PD. Keloids and hypertrophic scars. Dermatol Surg (1999) 25:631-8. doi:10.1046/j.1524-4725.1999.98257.x

51. Ogawa R, Akaishi S. Endothelial dysfunction may play a key role in keloid and hypertrophic scar pathogenesis - keloids and hypertrophic scars may be vascular disorders. Med Hypotheses (2016) 96:51-60. doi:10.1016/j. mehy.2016.09.024

52. Butzelaar L, Ulrich MM, Mink van der Molen AB, Niessen FB, Beelen RH. Currently known risk factors for hypertrophic skin scarring: a review. J Plast Reconstr Aesthet Surg (2016) 69:163-9. doi:10.1016/j.bjps.2015.11.015

53. Mustoe TA, Cooter RD, Gold MH, Hobbs F, Ramelet A-A, Shakespeare PG, et al. International clinical recommendations on scar management. Plast Reconstr Surg (2002) 110:560-71. doi:10.1097/00006534-200208000-00031

54. Gold MH, Berman B, Clementoni MT, Gauglitz GG, Nahai F, Murcia C. Updated international clinical recommendations on scar management: part 1 - evaluating the evidence. Dermatol Surg (2014) 40:817-24. doi:10.1111/ dsu. 0000000000000049

55. Burd A, Huang L. Hypertrophic response and keloid diathesis: two very different forms of scar. Plast Reconstr Surg (2005) 116:150e-7e. doi:10.1097/01. prs.0000191977.51206.43

56. Verhaegen PD, Van Zuijlen PP, Pennings NM, Van Marle J, Niessen FB, Van Der Horst CM, et al. Differences in collagen architecture between keloid, hypertrophic scar, normotrophic scar, and normal skin: an objective histopathological analysis. Wound Repair Regen (2009) 17:649-56. doi:10.1111/j. 1524-475X.2009.00533.x

57. Slemp AE, Kirschner RE. Keloids and scars: a review of keloids and scars, their pathogenesis, risk factors, and management. Curr Opin Pediatr (2006) 18:396-402. doi:10.1097/01.mop.0000236389.41462.ef

58. Lee JY, Yang CC, Chao SC, Wong TW. Histopathological differential diagnosis of keloid and hypertrophic scar. Am J Dermatopathol (2004) 26:379-84. doi:10.1097/00000372-200410000-00006

59. Ehrlich HP, Desmouliere A, Diegelmann RF, Cohen IK, Compton CC, Garner WL, et al. Morphological and immunochemical differences between keloid and hypertrophic scar. Am J Pathol (1994) 145:105-13.

60. Khansa I, Harrison B, Janis JE. Evidence-based scar management: how to improve results with technique and technology. Plast Reconstr Surg (2016) 138:165s-78s. doi:10.1097/prs.0000000000002647

61. Viera MH, Amini S, Valins W, Berman B. Innovative therapies in the treatment of keloids and hypertrophic scars. J Clin Aesthet Dermatol (2010) 3:20-6.

62. Carmichael SW. The tangled web of Langer's lines. Clin Anat (2014) 27:162-8. doi:10.1002/ca.22278 
63. Burke M. Scars. Can they be minimised? Aust Fam Physician (1998) 27:275-8.

64. Bloemen MC, van der Veer WM, Ulrich MM, van Zuijlen PP, Niessen FB, Middelkoop E. Prevention and curative management of hypertrophic scar formation. Burns (2009) 35:463-75. doi:10.1016/j.burns.2008.07.016

65. Ogawa R. The most current algorithms for the treatment and prevention of hypertrophic scars and keloids. Plast Reconstr Surg (2010) 125:557-68. doi:10.1097/PRS.0b013e3181c82dd5

66. Bleasdale B, Finnegan S, Murray K, Kelly S, Percival SL. The use of silicone adhesives for scar reduction. Adv Wound Care (New Rochelle) (2015) 4:422-30. doi:10.1089/wound.2015.0625

67. Chernoff WG, Cramer H, Su-Huang S. The efficacy of topical silicone gel elastomers in the treatment of hypertrophic scars, keloid scars, and post-laser exfoliation erythema. Aesthetic Plast Surg (2007) 31:495-500. doi:10.1007/ s00266-006-0218-1

68. Macintyre L, Baird M. Pressure garments for use in the treatment of hypertrophic scars - a review of the problems associated with their use. Burns (2006) 32:10-5. doi:10.1016/j.burns.2004.06.018

69. Del Toro D, Dedhia R, Tollefson TT. Advances in scar management: prevention and management of hypertrophic scars and keloids. Curr Opin Otolaryngol Head Neck Surg (2016) 24:322-9. doi:10.1097/moo.0000000000000268

70. Poetschke J, Gauglitz GG. Current options for the treatment of pathological scarring. J Dtsch Dermatol Ges (2016) 14:467-77. doi:10.1111/ddg.13027

71. Meaume S, Le Pillouer-Prost A, Richert B, Roseeuw D, Vadoud J. Management of scars: updated practical guidelines and use of silicones. Eur J Dermatol (2014) 24:435-43. doi:10.1684/ejd.2014.2356

72. Due E, Rossen K, Sorensen LT, Kliem A, Karlsmark T, Haedersdal M. Effect of UV irradiation on cutaneous cicatrices: a randomized, controlled trial with clinical, skin reflectance, histological, immunohistochemical and biochemical evaluations. Acta Derm Venereol (2007) 87:27-32. doi:10.2340/ 00015555-0154

73. Powers PS, Sarkar S, Goldgof DB, Cruse CW, Tsap LV. Scar assessment: current problems and future solutions. J Burn Care Rehabil (1999) 20:54-60; discussion 53. doi:10.1097/00004630-199901001-00011

74. Collins LK, Knackstedt TJ, Ganger P, Scherer E, Samie FH. Applying a visual assessment tool to facial linear scars. Facial Plast Surg (2017) 33:97-101. doi:10.1055/s-0036-1597684

75. Idriss N, Maibach HI. Scar assessment scales: a dermatologic overview. Skin Res Technol (2009) 15:1-5. doi:10.1111/j.1600-0846.2008.00327.x

76. Seo SR, Kang NO, Yoon MS, Lee HJ, Kim DH. Measurements of scar properties by SkinFibroMeter(R), SkinGlossMeter(R), and Mexameter(R) and comparison with Vancouver Scar Scale. Skin Res Technol (2016) 66:251-9. doi:10.1111/srt.12334

77. Reinholz M, Schwaiger H, Poetschke J, Epple A, Ruzicka T, Von Braunmuhl T, et al. Objective and subjective treatment evaluation of scars using optical coherence tomography, sonography, photography, and standardised questionnaires. Eur J Dermatol (2016) 26:599-608. doi:10.1684/ejd.2016. 2873

78. Poetschke J, Schwaiger H, Gauglitz GG. Current and emerging options for documenting scars and evaluating therapeutic progress. Dermatol Surg (2017) 43:25-36. doi:10.1097/dss.0000000000000698

79. Ren Y, Zhou X, Wei Z, Lin W, Fan B, Feng S. Efficacy and safety of triamcinolone acetonide alone and in combination with 5 -fluorouracil for treating hypertrophic scars and keloids: a systematic review and meta-analysis. Int Wound J (2017) 14:480-7. doi:10.1111/iwj.12629

80. Atiyeh BS. Nonsurgical management of hypertrophic scars: evidence-based therapies, standard practices, and emerging methods. Aesthetic Plast Surg (2007) 31:468-92. doi:10.1007/s00266-006-0253-y

81. Berman B, Perez OA, Konda S, Kohut BE, Viera MH, Delgado S, et al. A review of the biologic effects, clinical efficacy, and safety of silicone elastomer sheeting for hypertrophic and keloid scar treatment and management. Dermatol Surg (2007) 33:1291-302; discussion 302-3. doi:10.1111/j. 1524-4725.2007.33280.x

82. Mustoe TA. Evolution of silicone therapy and mechanism of action in scar management. Aesthetic Plast Surg (2008) 32:82-92. doi:10.1007/ s00266-007-9030-9

83. Signorini M, Clementoni MT. Clinical evaluation of a new self-drying silicone gel in the treatment of scars: a preliminary report. Aesthetic Plast Surg (2007) 31:183-7. doi:10.1007/s00266-005-0122-0
84. Hosnuter M, Payasli C, Isikdemir A, Tekerekoglu B. The effects of onion extract on hypertrophic and keloid scars. J Wound Care (2007) 16:251-4. doi:10.12968/jowc.2007.16.6.27070

85. Ocampo-Candiani J, Vazquez-Martinez OT, Iglesias Benavides JL, Buske K, Lehn A, Acker C. The prophylactic use of a topical scar gel containing extract of Allium cepae, allantoin, and heparin improves symptoms and appearance of cesarean-section scars compared with untreated scars. J Drugs Dermatol (2014) 13:176-82.

86. Cho JW, Cho SY, Lee SR, Lee KS. Onion extract and quercetin induce matrix metalloproteinase-1 in vitro and in vivo. Int J Mol Med (2010) 25:347-52.

87. Phan TT, Lim IJ, Chan SY, Tan EK, Lee ST, Longaker MT. Suppression of transforming growth factor beta/Smad signaling in keloid-derived fibroblasts by quercetin: implications for the treatment of excessive scars. J Trauma (2004) 57:1032-7. doi:10.1097/01.TA.0000114087.46566.EB

88. Prado A, Andrades P, Benitez S, Umana M. Scar management after breast surgery: preliminary results of a prospective, randomized, and double-blind clinical study with aldara cream 5\% (imiquimod). Plast Reconstr Surg (2005) 115:966-72. doi:10.1097/01.PRS.0000153823.52784.7E

89. Foo CW, Tristani-Firouzi P. Topical modalities for treatment and prevention of postsurgical hypertrophic scars. Facial Plast Surg Clin North Am (2011) 19:551-7. doi:10.1016/j.fsc.2011.06.008

90. Juckett G, Hartman-Adams H. Management of keloids and hypertrophic scars. Am Fam Physician (2009) 80:253-60.

91. Huang L, Cai YJ, Lung I, Leung BC, Burd A. A study of the combination of triamcinolone and 5-fluorouracil in modulating keloid fibroblasts in vitro. J Plast Reconstr Aesthet Surg (2013) 66:e251-9. doi:10.1016/j.bjps.2013. 06.004

92. Boutli-Kasapidou F, Tsakiri A, Anagnostou E, Mourellou O. Hypertrophic and keloidal scars: an approach to polytherapy. Int J Dermatol (2005) 44:324-7. doi:10.1111/j.1365-4632.2004.02570.x

93. Fitzpatrick RE. Treatment of inflamed hypertrophic scars using intralesional 5-FU.DermatolSurg (1999) 25:224-32. doi:10.1046/j.1524-4725.1999.08165.x

94. Asilian A, Darougheh A, Shariati F. New combination of triamcinolone, 5-fluorouracil, and pulsed-dye laser for treatment of keloid and hypertrophic scars. DermatolSurg(2006) 32:907-15. doi:10.1111/j.1524-4725.2006.32195.x

95. Ledon JA, Savas J, Franca K, Chacon A, Nouri K. Intralesional treatment for keloids and hypertrophic scars: a review. Dermatol Surg (2013) 39:1745-57. doi:10.1111/dsu. 12346

96. Larrabee WF Jr, East CA, Jaffe HS, Stephenson C, Peterson KE. Intralesional interferon gamma treatment for keloids and hypertrophic scars. Arch Otolaryngol Head Neck Surg (1990) 116:1159-62. doi:10.1001/archotol.1990. 01870100053011

97. Takeuchi M, Tredget EE, Scott PG, Kilani RT, Ghahary A. The antifibrogenic effects of liposome-encapsulated IFN-alpha2b cream on skin wounds. J Interferon Cytokine Res (1999) 19:1413-9. doi:10.1089/107999099312876

98. Gauglitz GG. Management of keloids and hypertrophic scars: current and emerging options. Clin Cosmet Investig Dermatol (2013) 6:103-14. doi:10.2147/CCID.S35252

99. Naeini FF, Najafian J, Ahmadpour K. Bleomycin tattooing as a promising therapeutic modality in large keloids and hypertrophic scars. Dermatol Surg (2006) 32:1023-9; discussion 9-30. doi:10.1111/j.1524-4725.2006.32225.x

100. Aggarwal H, Saxena A, Lubana PS, Mathur RK, Jain DK. Treatment of keloids and hypertrophic scars using bleom. J Cosmet Dermatol (2008) 7:43-9. doi:10.1111/j.1473-2165.2008.00360.x

101. Ahuja RB, Chatterjee P. Comparative efficacy of intralesional verapamil hydrochloride and triamcinolone acetonide in hypertrophic scars and keloids. Burns (2014) 40:583-8. doi:10.1016/j.burns.2013.09.029

102. Margaret Shanthi FX, Ernest K, Dhanraj P. Comparison of intralesional verapamil with intralesional triamcinolone in the treatment of hypertrophic scars and keloids. Indian J Dermatol Venereol Leprol (2008) 74:343-8. doi:10.4103/0378-6323.42899

103. Ziade M, Domergue S, Batifol D, Jreige R, Sebbane M, Goudot P, et al. Use of botulinum toxin type A to improve treatment of facial wounds: a prospective randomised study. J Plast Reconstr Aesthet Surg (2013) 66:209-14. doi:10.1016/j.bjps.2012.09.012

104. Xiao Z, Zhang M, Liu Y, Ren L. Botulinum toxin type a inhibits connective tissue growth factor expression in fibroblasts derived from hypertrophic scar. Aesthetic Plast Surg (2011) 35:802-7. doi:10.1007/s00266-011-9690-3 
105. Xiao Z, Zhang F, Cui Z. Treatment of hypertrophic scars with intralesional botulinum toxin type A injections: a preliminary report. Aesthetic Plast Surg (2009) 33:409-12. doi:10.1007/s00266-009-9334-Z

106. Durani P, Occleston N, O'Kane S, Ferguson MW. Avotermin: a novel antiscarring agent. Int J Low Extrem Wounds (2008) 7:160-8. doi: $10.1177 / 1534734608322983$

107. Occleston NL, O'kane S, Laverty HG, Cooper M, Fairlamb D, Mason T, et al. Discovery and development of avotermin (recombinant human transforming growth factor beta 3): a new class of prophylactic therapeutic for the improvement of scarring. Wound Repair Regen (2011) 19(s1):s38-48. doi:10.1111/j.1524-475X.2011.00711.x

108. Tziotzios C, Profyris C, Sterling J. Cutaneous scarring: pathophysiology, molecular mechanisms, and scar reduction therapeutics Part II. Strategies to reduce scar formation after dermatologic procedures. J Am Acad Dermatol (2012) 66:13-24. doi:10.1016/j.jaad.2011.08.035

109. Engrav LH, Heimbach DM, Rivara FP, Moore ML, Wang J, Carrougher GJ, et al. 12-Year within-wound study of the effectiveness of custom pressure garment therapy. Burns (2010) 36:975-83. doi:10.1016/j.burns.2010.04.014

110. Anzarut A, Olson J, Singh P, Rowe BH, Tredget EE. The effectiveness of pressure garment therapy for the prevention of abnormal scarring after burn injury: a meta-analysis. J Plast Reconstr Aesthet Surg (2009) 62:77-84. doi:10.1016/j.bjps.2007.10.052

111. Li-Tsang CW, Zheng YP, Lau JC. A randomized clinical trial to study the effect of silicone gel dressing and pressure therapy on posttraumatic hypertrophic scars. J Burn Care Res (2010) 31:448-57. doi:10.1097/BCR.0b013e3181db52a7

112. Reno F, Grazianetti P, Stella M, Magliacani G, Pezzuto C, Cannas M. Release and activation of matrix metalloproteinase- 9 during in vitro mechanical compression in hypertrophic scars. Arch Dermatol (2002) 138:475-8. doi:10.1001/archderm.138.4.475

113. Reno F, Grazianetti P, Cannas M. Effects of mechanical compression on hypertrophic scars: prostaglandin E2 release. Burns (2001) 27:215-8. doi:10.1016/S0305-4179(00)00101-7
114. Weshahy AH, Abdel Hay R. Intralesional cryosurgery and intralesiona steroid injection: a good combination therapy for treatment of keloids and hypertrophic scars. Dermatol Ther (2012) 25:273-6. doi:10.1111/j. 1529-8019.2012.01456.x

115. Ogawa R, Akaishi S, Huang C, Dohi T, Aoki M, Omori Y, et al. Clinical applications of basic research that shows reducing skin tension could prevent and treat abnormal scarring: the importance of fascial/subcutaneous tensile reduction sutures and flap surgery for keloid and hypertrophic scar reconstruction. JNippon Med Sch (2011) 78:68-76. doi:10.1272/ jnms.78.68

116. Koike S, Akaishi S, Nagashima Y, Dohi T, Hyakusoku H, Ogawa R. Nd:YAG laser treatment for keloids and hypertrophic scars: an analysis of 102 cases. Plast Reconstr Surg Glob Open (2014) 2:e272. doi:10.1097/ gox.0000000000000231

117. Vrijman C, van Drooge AM, Limpens J, Bos JD, van der Veen JP, Spuls PI, et al. Laser and intense pulsed light therapy for the treatment of hypertrophic scars: a systematic review. Br J Dermatol (2011) 165:934-42. doi:10.1111/j.1365-2133.2011.10492.x

118. Allison KP, Kiernan MN, Waters RA, Clement RM. Pulsed dye laser treatment of burn scars. Alleviation or irritation? Burns (2003) 29:207-13.

Conflict of Interest Statement: The authors declare that the research was conducted in the absence of any commercial and financial relationships that could be construed as a potential conflict of interest.

Copyright (c) 2017 Mokos, Jović, Grgurević, Dumić-Čule, Kostović, Čeović and Marinović. This is an open-access article distributed under the terms of the Creative Commons Attribution License (CC BY). The use, distribution or reproduction in other forums is permitted, provided the original author(s) or licensor are credited and that the original publication in this journal is cited, in accordance with accepted academic practice. No use, distribution or reproduction is permitted which does not comply with these terms. 